\title{
A new molecular targeted therapeutic approach for renal cell carcinoma with a p16 functional peptide using a novel transporter system
}

\author{
KENJI ZENNAMI $^{1}$, KAZUHIRO YOSHIKAWA ${ }^{1}$, EISAKU KONDO ${ }^{4}$, KOGENTA NAKAMURA $^{1}$, \\ YOSHIAKI YAMADA ${ }^{1}$, MARCO A. DE VELASCO ${ }^{3}$, MOTOYOSHI TANAKA ${ }^{3}$, HIROTSUGU UEMURA ${ }^{3}$, \\ TORU SHIMAZUI ${ }^{4}$, HIDEYUKI AKAZA ${ }^{5}$, SHINSUKE SAGA ${ }^{6}$, RYUZO UEDA ${ }^{7}$ and NOBUAKI HONDA ${ }^{1}$
}

\begin{abstract}
${ }^{1}$ Department of Urology, Aichi Medical University School of Medicine, Nagakute, 480-1195 Aichi; ${ }^{2}$ Division of Oncological Pathology, Aichi Cancer Center Research Institute, Nagoya, 464-8681 Aichi; ${ }^{3}$ Department of Urology, Kinki University School of Medicine, Osaka-Sayama, 589-8511 Osaka; ${ }^{4}$ Department of Urology, Graduate School of Comprehensive Human Sciences, University of Tsukuba, Tsukuba, 305-8575 Ibaraki; ${ }^{5}$ Department of Strategic Investigation on Comprehensive Cancer Network Research Center for advanced Science and Technology, The University of Tokyo, Meguro-ku, 153-8904 Tokyo; ${ }^{5}$ Department of Pathology, Aichi Medical University School of Medicine and ${ }^{6}$ Nagoya

City University Graduate School of Medical Sciences, Nagoya, 467-8601 Aichi, Japan
\end{abstract}

Received February 4, 2011; Accepted March 8, 2011

DOI: 10.3892/or.2011.1290

\begin{abstract}
Molecular targeting agents have become formidable anticancer weapons showing much promise against refractory tumors and functional peptides and are among the more desirable of these nanobio-tools. Intracellular delivery of multiple functional peptides forms the basis for a potent, non-invasive mode of delivery, providing distinctive therapeutic advantages. We examine the growth suppression efficiency of human renal cell carcinoma (RCC) by singlepeptide targeting. We simultaneously introduced $\mathrm{p} 16^{\mathrm{INK} 4_{\mathrm{a}}}$ tumor suppressor peptides by Wr-T-mediated peptide delivery. Wr-T-mediated transport of p1 $^{\text {INK4a }}$ functional peptide into 10 $\mathrm{RCC}$ lines, lacking expression of the $\mathrm{p} 16^{\mathrm{INK} 4 \mathrm{a}}$ molecule, reversed the specific loss of p16 function, thereby drastically inhibiting tumor growth in all but 3 lines by $>95 \%$ within the first $96 \mathrm{~h}$. In vivo analysis using SK-RC-7 RCC xenografts in nude mice demonstrated tumor growth inhibition by the $\mathrm{p} 16^{\mathrm{INK4a}}$ peptide alone, however, inoculation of $\mathrm{Wr}-\mathrm{T}$ and the $\mathrm{p} 16^{\mathrm{INK} 4 \mathrm{a}}$ functional peptide mixture, via the heart resulted in complete tumor regression. Thus, restoration of tumor suppressor function with Wr-T peptide delivery represents a powerful approach, with mechanistic implications for the development of efficacious molecular targeting therapeutics against intractable RCC.
\end{abstract}

Correspondence to: Dr Kazuhiro Yoshikawa, Division of Clinical Research Promotion, Aichi Medical University, Nagakute, Aichi 480-1195, Japan

E-mail: yoshikaw@aichi-med-u.ac.jp

Key words: PTD, p16, renal cell carcinoma

\section{Introduction}

Renal cell carcinoma does not respond to chemotherapy or radiation therapy. In addition, unresectable recurrences or metastases have been treated only by cytokine therapy with INF or IL-2, which is not so effective, with a response rate of about $10-20 \%$ (1-6). Recently, tyrosine-kinase-targeting inhibitors (such as sorafenib, sunitinib, everolimus and temsirolimus), which are involved in the growth of cancer cells, and other signal transduction inhibitors have been developed for use in molecular targeted therapy and are beginning to be indicated for the treatment of metastatic renal cancer (7-12). Although these molecular targeting drugs are more effective than cytokine therapy, they have not provided satisfactory therapeutic results. Moreover, tyrosine-kinase inhibitors are associated with adverse reactions, including hand-foot syndrome and hypertension, while m-TOR inhibitors may cause adverse reactions such as interstitial pneumonia. Therefore, there is a need for the continued development of more effective therapeutic agents associated with fewer adverse reactions for the treatment of renal cell carcinoma.

Protein transduction domains (PTDs) have recently been receiving attention as safe and effective tools in intracellular drug delivery systems. PTDs, being able to pass through the cell membrane of living cells, are considered useful for intracellular delivery of functional proteins or peptides targeting intracellular molecules, and many PTDs, including HIV-1 TAT, pAntp43-58 and polyarginine (R4-16), have been reported (13-23). In 1998, Nagahara et al produced a recombinant protein (TAT-p27 $7^{\mathrm{kipl}}$ fusion protein), transduced it into cells, and induced G1 arrest and cell migration (16). Kondo et al developed a system through which functional peptides and their transporter peptides were synthesized separately and attached to each other by mixing into a solution, and the 
Table I. PCR primers and condition.

\begin{tabular}{|c|c|c|c|}
\hline Molecule & Sequences & Annealing temperature $\left({ }^{\circ} \mathrm{C}\right)$ & Fragment (bp) \\
\hline p16 & $\begin{array}{l}\text { F: ATAGTTACGGTCGGAGGCC } \\
\text { R: TGGTTACTGCCTCTGGTGC }\end{array}$ & 60 & 536 \\
\hline Cyclin D & $\begin{array}{l}\text { F: AAAGACAGTTTTTGGGTAATCTTTT } \\
\text { R: CCGGAGCATTTTGATACCAG }\end{array}$ & 55 & 126 \\
\hline CDK4 & $\begin{array}{l}\text { F: CTTCTGGACACTGAGAGGGC } \\
\text { R: TGGGAGGGGAATGTCATTAA }\end{array}$ & 61 & 110 \\
\hline CDK6 & $\begin{array}{l}\text { F: CGGAGAACACCCTTGGTG } \\
\text { R: GAGCCTGTCCAGAAGACAGC }\end{array}$ & 59 & 105 \\
\hline Actin & $\begin{array}{l}\text { F: GTGGGGCGCCCCAGGCACCA } \\
\text { R: CTCCTTAATGTCACGCACGATTTC }\end{array}$ & 55 & 539 \\
\hline
\end{tabular}

resulting complex was then used to deliver functional peptides to cells, instead of a system through which PTDs were directly bound to functional peptides or proteins. This transporter, Wr-T, consisted of tryptophan-rich domains (serving as a cargo to attach functional peptides) fused with nine $\mathrm{D}$-arginines serving as a PTD. They reported that the Wr-T system provided higher delivery efficiency than Pep-1 (whose delivery efficiency is already reported) and achieved an antitumor effect by delivering antitumor peptides to leukemia, lymphoma and glioma cells (21-23). In the present study, we delivered antitumor peptides to renal cell carcinoma cell lines using a similar system, and evaluated their antitumor effect. The antitumor peptides showed a strong antitumor effect on renal cell carcinoma without causing any abnormalities in normal tissues. This finding indicates that this therapy, associated with few adverse reactions, shows promise for clinical application in cancer treatment.

\section{Materials and methods}

Cells. Human RCC lines SK-RC-1, 6, 7, 12, 14, 17, 33, 44, 52 and 59 (kindly provided by Dr Lloyd J. Old, MSKCC), human cervical cancer cell line (HeLa) and human bladder cancer cell line (575A) were maintained in RPMI-1640 containing $10 \%$ inactivated fetal bovine serum (IBL, Gunma, Japan), $100 \mathrm{U} / \mathrm{ml}$ of penicillin and $0.1 \mathrm{mg} / \mathrm{ml}$ of streptomycin, at $37^{\circ} \mathrm{C}$ under an atmosphere of $5 \% \mathrm{CO}_{2}$.

Peptide synthesis. All peptides including Wr-T, r9-p16 minimal inhibitory sequence (MIS) were synthesized at BioGate Co. Ltd. (Yamagata, Japan). The identity of all peptides was confirmed by mass spectrometry. We prepared the $\mathrm{HCl}$ form of the peptides following high-performance liquid chromatography purification for in vitro and in vivo applications. Peptide purity was $>95 \%$. The amino acid sequence of the Wr-T transporter is: KETWWETWWTEWWTEWSQ GPGrrrrrrrrr (r, D-enantiomer arginine) $(21,22)$. For the synthesis of p16 MIS, the 10 sequential amino acid residue sequence 'FLDTLVVLHR', identified as the MIS of p16 by Fahraeus et al (24), was defined as the functional core of the peptide, which is insoluble, as is the entire p16 molecule (MIS hydrophobicity, $69.2 \%)$. We therefore fused $\mathrm{r} 9$ to these 10 amino acids to make the conjugate less hydrophobic (hydrophobicity, $40 \%$ ), thus facilitating incorporation into the cells.

Peptide transduction. For the incorporation of the peptide mixture for in vitro growth suppression, the Wr-T and r9-p16 MIS peptides were mixed in $10 \mu \mathrm{l}$ of distilled water at room temperature for $60 \mathrm{~min}$ (final concentration: Wr-T, $5 \mu \mathrm{mol} / \mathrm{l}$; r9-p16 MIS, $8 \mu \mathrm{mol} / \mathrm{l})$. The solution was then added directly to $190 \mu \mathrm{l}$ of RPMI-1640 containing $5 \%$ fetal bovine serum to obtain the indicated final concentration. In vivo peptide delivery to solid human RCC was performed as follows: the Wr-T/r9-p16 MIS peptide mix (Wr-T, 50 nmol; r9-p16 MIS, $80 \mathrm{nmol}$ ) was injected into the hearts of mice bearing tumors that had grown to a diameter of $5 \mathrm{~mm}$ (tumor volume, $\sim 150 \mathrm{~mm}^{3}$ ). Control groups were done in parallel by administering $100 \mu \mathrm{l}$ of PBS without peptide, Wr-T or p16 peptide alone dissolved in $100 \mu \mathrm{l}$ of PBS and injected as previously described (22).

Flow cytometry. Cell cycle analysis was carried out using FACSCanto (BD, Franklin Lakes, USA) on cells whose DNA was stained with $10 \mathrm{mg} / \mathrm{ml}$ propidium iodide $24 \mathrm{~h}$ after the introduction of the peptides, according to the manufacturer's staining protocol (cell cycle analysis, GeneScript, Piscataway, NJ, USA). Apoptosis assays were performed using the FITCAnnexin V staining kit (MBL, Ina, Japan) on peptide-treated cells followed by FACSCanto analysis.

Reverse transcription PCR. Five micrograms of total RNA was extracted from each SK-RC/575A cell line using RNaesy mini (Qiagen, Valencia, CA, USA). Subsequently, cDNA was synthesized from the extracted RNA using random primers and a cDNA synthesis kit (High Capacity cDNA RT Kit, Applied Biosystems, Foster City, CA USA). Reverse transcription-PCR was then carried out with Taq polymerase (Ampli-Taq Gold, Applied Biosystems). Amplification conditions and primer sequences are listed in Table I. The sense/antisense primer sequences for CDK4, CDK6 and Cyclin D were as described previously (25).

Western blotting. Cells were promptly lysed with SDS sample lysis buffer and the extracts were separated by SDS-PAGE using 12.5-15\% bis-Tris gradient gels (SuperSepAce, Wako, Osaka, 
Japan). Proteins were transferred onto a PVDF-membrane (Immobilon-P, Millipore, Billerica, MA, USA), blocked with 5\% dried milk and $1 \%$ normal goat serum-PBS and then sequentially probed with the following antibodies: mouse monoclonal antip16 ${ }^{\mathrm{INK} 4}$ antibody (Clone: G175-1239, BD Biosciences Pharmingen, San Diego, CA, USA), mouse monoclonal anti-p21 ${ }^{\text {WAF1 }}$ antibody (Clone: EA10, Oncogene Research Products, Boston, MA, USA), mouse monoclonal anti-p27 ${ }^{\mathrm{Kip} 1}$ antibody (Clone: 1B4, Novocastra, Newcastle, UK), mouse monoclonal anti-RB antibody (Clone: LM95.1, Oncogne), rabbit polyclonal antiphospho-Ser ${ }^{780}$ pRB antibody (Cell Signaling Technology, Danvers, MA, USA), mouse monoclonal anti-actin antibody (Clone: AC-74, Sigma, St. Louis, MO, USA). Immune-complexes were visualized with the ECL plus Western Blotting Detection System (RPN2132, Amersham Pharmacia Biotech UK Limited, UK) according to the manufacturer's instructions and signals were visualized and digitally captured using an image analyzer (LAS 1000, Fuji Photo Film Co. Ltd., Tokyo, Japan).

Mouse tumor models. Four-week-old KSN female nude mice were obtained from SLC, Inc. (Hamamatsu, Japan). A 40- $\mu 1$ of RPMI-1640 suspension containing $2.0 \times 10^{6}$ cells of the human RCC line, SK-RC-7, was injected s.c. into the flanks of each mouse to form a solid tumor nodule. Animal experiments performed in this study were approved by the Aichi Medical University Subcommittee on Animal Research. All mouse procedures, euthanasia and surgery, including renal cell cancer transplantations and peptide injections, were done painlessly or under anesthesia, within the strict guidelines of the Experimental Animal Facility of Aichi Medical University.

Apoptosis analysis. Detection of apoptotic cells were detected in tumors harvested from mice $48 \mathrm{~h}$ after the peptide administration. Tumors were fixed in $10 \%$ neutral buffered formalin overnight and were then processed, paraffin embedded, sectioned and mounted onto slides. Apoptosis in the tumor sections was determined by the terminal deoxynucleotidyl transferasemediated dUTP-biotin nick-end labeling (TUNEL) assay method with the use of the In Situ Cell Death Detection Kit (Roche Diagnostics, Tokyo, Japan) following the manufacturer's instructions.

\section{Results}

INK4 family tumor suppressor background in RCC. We first examined the mRNA and protein expression status of p16 and several key molecules associated with the cell cycle from 10 RCC lines. Immunoblotting analysis showed that none of the 10 RCC lines expressed the p16 protein product, but expressed p27 protein, and 6 out of 10 cell lines expressed p21 protein, all renal cancer cell lines expressed the phosphorylated form of the pRB protein (Fig. 1A). Consistent with this non-expression of the p16 molecule, multiple forms of phosphorylated pRB, including $\mathrm{Ser}^{780}$, were detected in these cells, indicating $\mathrm{pRb}$ activation along with accelerated cell proli-feration. In addition, RT-PCR analysis detected Cyclin D, CDK4 and CDK6 in RNAs from all 10 RCC lines, but not p16 (Fig. 1B).

Growth inhibition of RCCs by the Wr-T/r9-pl6 transduction system. Based on these results, we attempted to suppress the

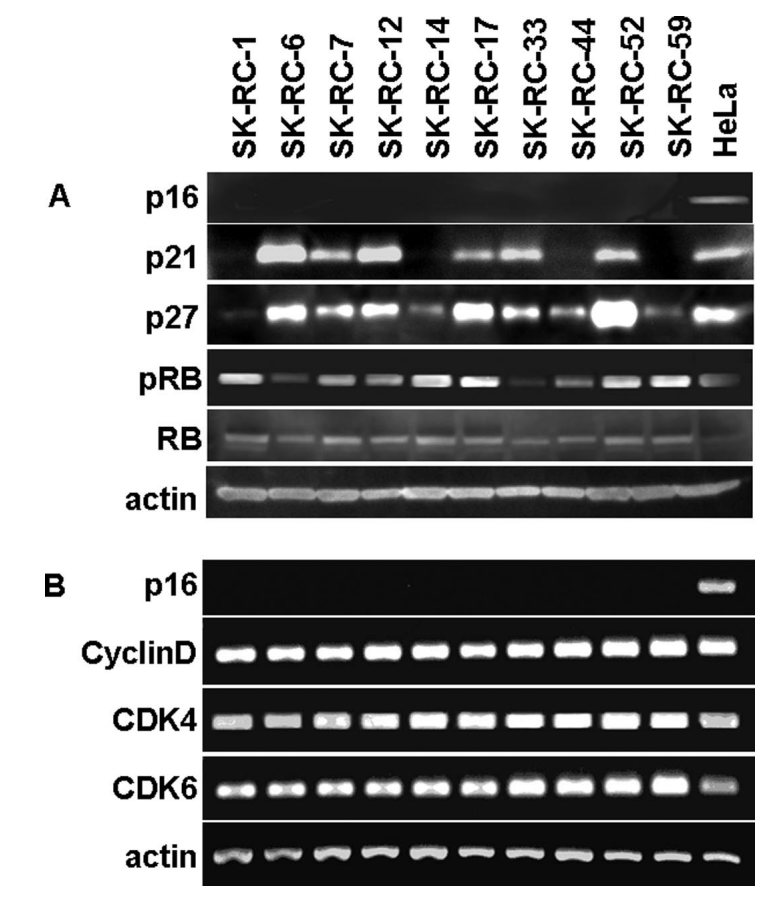

Figure 1. Loss of $16^{\mathrm{INK} 4 \mathrm{a}}$ expression was correlated to cell cycle pathway genes in 10 human renal cell carcinoma cell lines by Western blotting and RT-PCR. (A) Endogenous protein expression of $\mathrm{p} 16^{\mathrm{INK4a}}, \mathrm{p} 21^{\mathrm{Cipl}}, \mathrm{p} 27^{\mathrm{Kip} 1} \mathrm{RB}$ and phospho-Ser ${ }^{780} \mathrm{pRB}$ in the examined cell lines by immunoblotting. (B) endogenous mRNA expression of p16 ${ }^{\mathrm{INK} 4 \mathrm{a}}$, Cyclin D, CDK4, CDK6 and actin by reverse transcription-PCR in 10 human renal cell carcinoma cell lines, SK-RC-1, 6, 7, 12, 14, 17, 33, 44, 52 and 59.

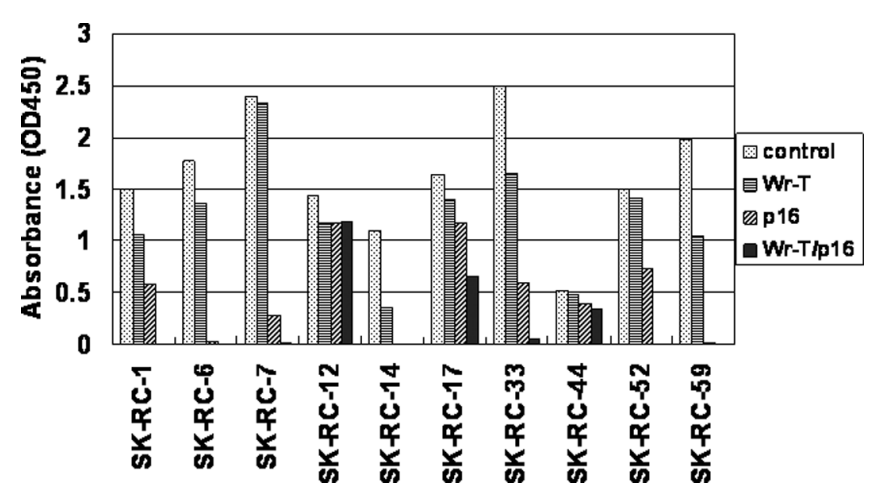

Figure 2. Cell growth suppression by transduction of Wr-T and p16 peptides. Ten representative cases of renal cell carcinoma cell lines are shown. Proliferation of cells treated with the Wr-T and p16 peptides mixture (Wr-T, $5 \mu \mathrm{mol} / 1$; p16 MIS, $8 \mu \mathrm{mol} / 1)$ was compared with cells treated without peptides, with Wr-T $(5 \mu \mathrm{mol} / \mathrm{l})$ alone and with p16 $(8 \mu \mathrm{mol} / \mathrm{l})$ alone using WST-1 assay.

growth of RCC cells by using the Wr-T-transported r9-p16 MIS. We introduced r9-p16 MIS into this background by mixing each RCC line with Wr-T (final concentration: Wr-T, $5 \mu \mathrm{mol} / \mathrm{l}$; r9-p16 MIS, $8 \mu \mathrm{mol} / \mathrm{l}$ ) and monitoring cell proliferation, starting with $4.0 \times 10^{4}$ cells per incubation. Administration of r9-p16 MIS alone showed some growth suppression in 7/10 cell lines. However, all tumor lines incubated with the Wr-T/r9-p16 MIS mixture showed drastic suppression of cell proli-feration (Fig. 2). At $24 \mathrm{~h}$ posttransduction, FACS analysis with propidium iodide staining 


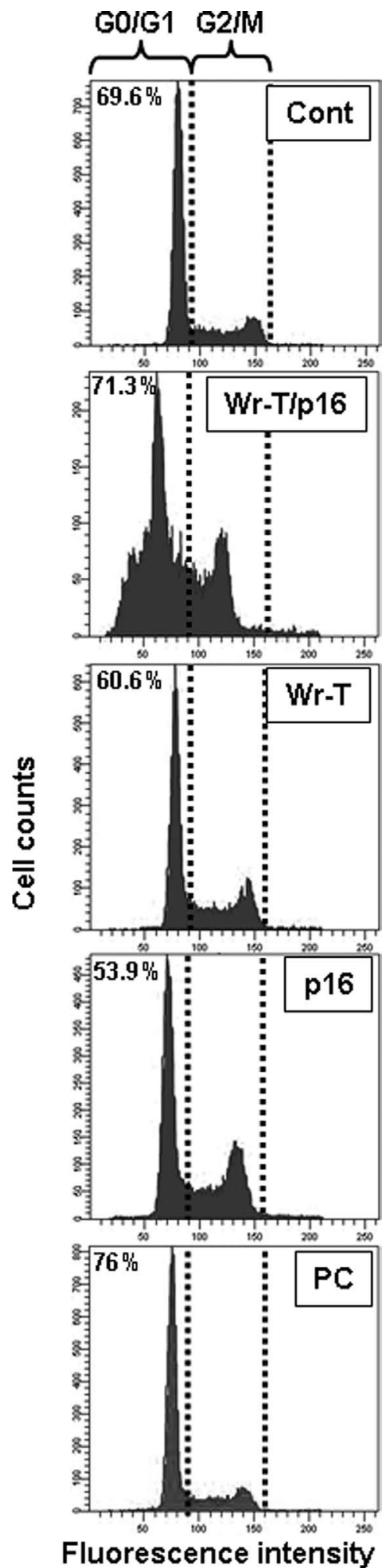

Figure 3. Enlarged G0-G1 phase in renal cell carcinoma cells treated with Wr-T and p16 peptides mixture. Cell cycle profiles of propidium iodide stained SK-RC-7 cells transduced with the Wr-T and p16 peptides mixture (Wr-T, $5 \mu \mathrm{mol} / 1$; p16 MIS, $6 \mu \mathrm{mol} / 1)$, without peptides, with Wr-T ( $5 \mu \mathrm{mol} / \mathrm{l})$ alone, and with p16 $(6 \mu \mathrm{mol} / \mathrm{l})$ alone $24 \mathrm{~h}$ after treatment. Percentage of cells in G0-G1 phase is indicated.

showed that SK-RC-7 cells incubated with the Wr-T/r9-p16 MIS mixture preferentially accumulated at the G0-G1 (71.3\%) phase, compared with mock-treated cells (69.6\%) and cells

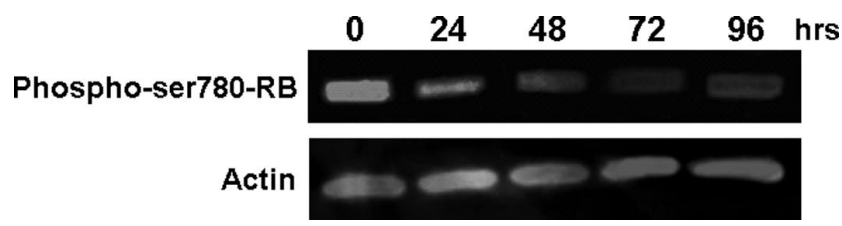

Figure 4. Reduced expression of phospho-Ser ${ }^{780}$ pRB in Wr-T/r9-p16 MISintroduced cells assessed by immunoblotting (Wr-T, $5 \mu \mathrm{mol} / 1 ; \mathrm{p} 16,8 \mu \mathrm{mol} / 1$ ).

treated only with r9-p16 MIS (53.9\%) (Fig. 3). This result was similar to that obtained with cells treated with staurosporin, a G0-G1 cell cycle inhibitor (26). Because arrest in G1 phase is expected to abrogate phosphorylation of $\mathrm{pRB}$, we investigated the practical effect that the Wr-T/r9-p16 MIS mixture would have on pRB status. By $72 \mathrm{~h}$ post-transduction, phospholylated pRB was dramatically decreased in cells containing the $\mathrm{Wr}-\mathrm{T} /$ r9-p16 MIS mixture, which is consistent with the induction of cell cycle arrest effected by the newly introduced p16 MIS (Fig. 4). About $52 \%$ of these cells were Annexin V positive at $24 \mathrm{~h}$ post-transduction, suggesting that the nuclear r9-p16 MIS had triggered apoptosis (Fig. 5).

In vivo RCC tumor suppression by the Wr-T/r9-p16 transduction system. Because of the therapeutic potential of the Wr-T/r9-p16 MIS delivery system, we tested the efficacy of this system for the treatment of the human RCC line, SKRC-7, xenografts transplanted subcutaneously in KSN nude mice. When tumors grew to $5 \mathrm{~mm}$, we administered the Wr-T/r9-p16 MIS mixture into the mice via cardiac delivery. A clear decrease in tumor size was evident after the first ten days in the mice treated with a single dose of the Wr-T/r9-p16 MIS mixture, whereas the peptide free tumors grew to twice their initial size. In addition, sustained suppression of tumor growth continued to 28 days in mice treated with three doses of the Wr-T/r9-p16 MIS mixture, though tumor growth eventually resumed in mice receiving only a single dose (Fig. 6A and B). At $48 \mathrm{~h}$ post-transduction, TUNEL analysis showed an increase in the presence of positively stained apoptotic bodies in tumor treated with the Wr-T/r9-p16 MIS mixture (Fig. 6C), suggesting that the nuclear incorporation of the r9-p16 MIS had triggered apoptosis.

\section{Discussion}

Cancer cells grow abnormally, probably because they have escaped the cell cycle control present in normal cells. One example is cell cycle progression caused by overexpression of Cyclin D1 due to translocation or amplification of the PRAD1 gene (27). Another example is cell cycle progression mediated by cyclin (which does not work in normal cells) due to the absence of cyclin inhibitors, such as $\mathrm{p} 16^{\mathrm{INK} 4 \mathrm{a}}$ and $\mathrm{p} 27^{\mathrm{Kip} 1}$ (28). Several reports are available on the expression of molecules involved in the cell-cycle process in patients with renal cell carcinoma. Ikuerowo et al analyzed the expression of $\mathrm{p} 16^{1 \mathrm{NK} 4 \mathrm{a}}$ in tumor samples from renal cell carcinoma using immunostaining, and observed absent or low expression of this gene in $82 \%$ of samples (29). Scharml et al performed microarray analysis and reported cyclin-dependent kinase inhibitor $2 \mathrm{~A}$ 


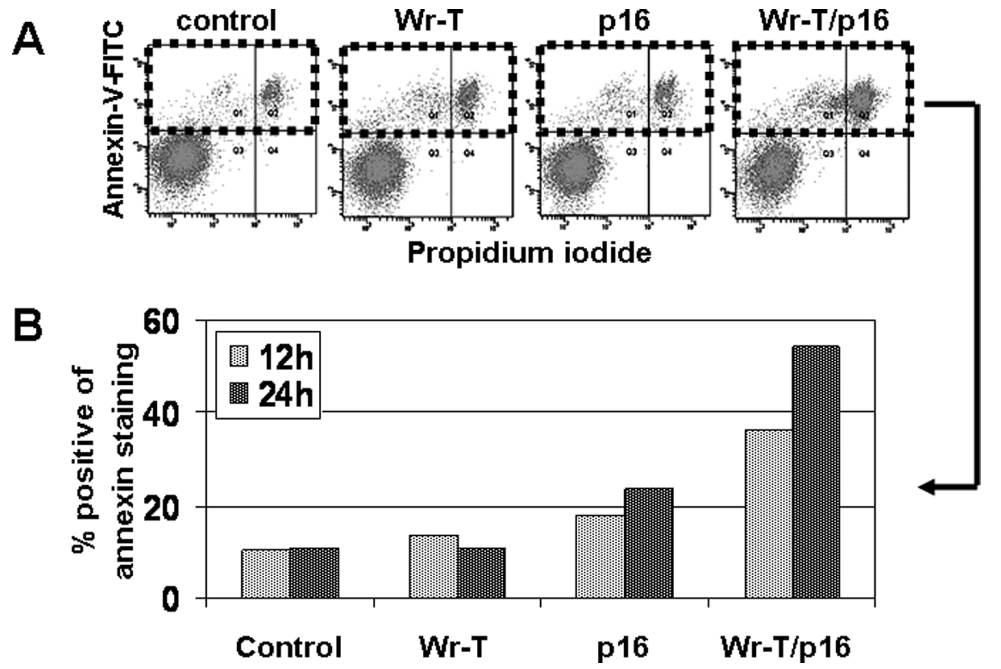

Figure 5. Apoptotic induction of renal cell carcinoma cells treated with Wr-T and p16 peptides mixture. The SK-RC-7 cells were treated with the Wr-T and p16 peptides mixture (Wr-T, $5 \mu \mathrm{mol} / 1$; p16 MIS, $8 \mu \mathrm{mol} / \mathrm{l}$ ), without peptides, with Wr-T ( $5 \mu \mathrm{mol} / \mathrm{l})$ alone, and with p16 ( $8 \mu \mathrm{mol} / \mathrm{l})$ alone. (A) Flow cytometry profiles of live, apoptotic and necrotic cells at 12 and $24 \mathrm{~h}$ after the treatment by staining with Annexin V-FITC and propidium iodide. (B) Columns, percentages of Annexin V-positive cells in each indicated sample from (A).

A

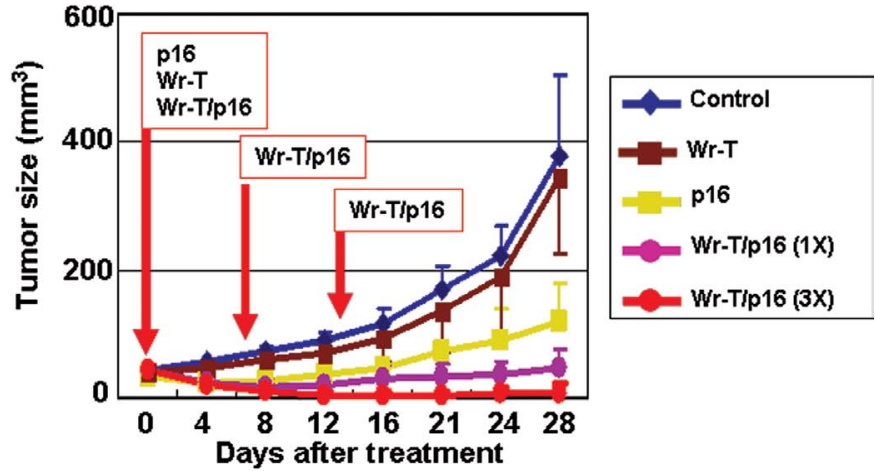

B

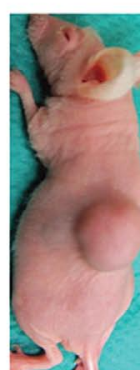

Control

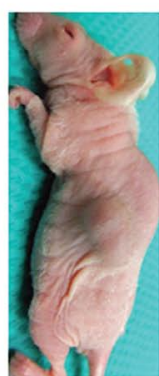

Wr-T

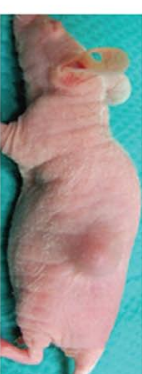

p16

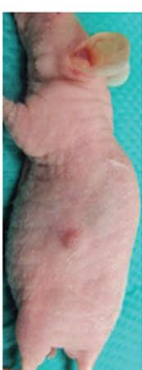

Wr-T/p16 Wr-T/p16 $1 \mathrm{x}$ injection 3x injection

C

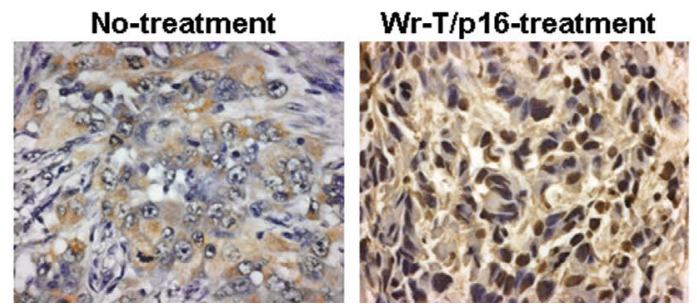

Figure 6. Effects of in vivo administration of Wr-T and p16 peptides mixture on tumor growth. SK-RC-7 cells $\left(1 \times 10^{6}\right)$ were transplanted into the backs of the nude mice. Treatments were performed as described in Materials and methods using 5 mice in each group. (A) Growth curves of tumors. Sizes of the tumors were determined by first measuring length (L) and width (W) and then the tumor volume (0.4 x L x W2) was calculated, values shown are the mean of five tumors $\left(\mathrm{mm}^{3}\right)$; bars; SD. (B) Tumor xenografts 28 days after treatment. (C) Representative photomicrograph showing the presence of apoptotic bodies detected by the TUNEL method in a tumor sample from a mouse 28 days after treatment with Wr-T and p16 peptide mixture (right), note the absence of apoptotic cells in an untreated sample (left). 
(CDKNA2A, p16 ${ }^{\mathrm{INK} 4 \mathrm{a}}$ ) expression only in 6 of 532 patients with clear cell renal cell carcinoma (30). In Japan, Kawada et al reported that only 7 of 91 patients did not show p16 $6^{\mathrm{INK} 4 a}$ expression (31). These findings suggested racial differences. However, our results were contrary to those obtained by Kawada et al (data not shown). Specifically, we studied the expression of cyclin inhibitors in renal cell carcinoma cell lines and patients with this disease using immunostaining, and found that none of the cell lines showed $\mathrm{p} 16^{\mathrm{INK} 4 \mathrm{a}}$ expression by Western blotting and that some of the cell lines did not show p2 $7^{\text {Kip1 }}$ expression, either; in addition, cell lines from only 2 of 84 renal cell carcinomas stained positive. During our study, phosphorylated $\mathrm{Rb}$ was detected in all renal cell carcinoma cell lines studied (Fig. 1). This finding suggests dysfunction of cyclin inhibitors and thus the possibility that the growth of renal cell carcinoma cells may be inhibited if the function of cyclin inhibitors is restored. Presuming that many Japanese patients with renal cell carcinoma show no $\mathrm{p} 16^{\mathrm{INK} 4 \mathrm{a}}$ expression, we thought it useful to establish a new cancer therapy targeting p16 $6^{\mathrm{INK} 4 \mathrm{a}}$ in the present study.

We therefore synthesized the amino acid sequence representing the minimal function of $\mathrm{p} 16^{\mathrm{INK} 4 \mathrm{a}}$, and delivered this sequence to renal cell carcinoma cell lines using an intracellular peptide/protein delivery system, which had already been established by our group. As a result, cell growth was almost completely inhibited in 7 of the 10 cell lines (Fig. 2). The reason for the poor response in the remaining 3 cell lines is still unknown, but there seems to be another cell-growthregulating system. Although the $\mathrm{p} 16^{\mathrm{INK} 4 \mathrm{a}}$ peptide, as well as the PTD of our peptide/protein delivery system, has a sequence consisting of 9 arginines, $\mathrm{p} 16^{\mathrm{INK} 4 \mathrm{a}}$ used as a complex with the peptide/protein delivery system was found to be more effective than $16^{\mathrm{INK} 4 \mathrm{a}}$ used alone. Different effects were shown when the same PTD was used. This finding suggests that the efficiency of peptide delivery is affected not only by the PTD itself but also by the sequence of the peptides-binding site. It seems that p16 ${ }^{\text {INK4a }}$ impairs the function of the Cyclin D-CDK4/6 complex and thus inhibits $\mathrm{Rb}$ phosphorylation, because this complex induces $\mathrm{Rb}$ phosphorylation. In cells transduced with the p16 ${ }^{\text {INK4a }}$ peptide, $\mathrm{Rb}$ phosphorylation is inhibited and the delivered peptide seems to function in place of the normal p16 ${ }^{\mathrm{INK4a}}$ molecule (Fig. 4). In our previous report on B cell lymphoma, cells with the peptide showed G1 arrest and induction of apoptosis. In addition, the number of renal cell carcinoma cells in the G2/M phase obviously decreased and that of cells in the G1/G0 phase increased, suggesting G1 arrest in renal cell carcinoma cells (Fig. 3). Moreover, apoptosis seemed to have been induced in such cells, because Annexin V-positive cells increased over time, with no cells negative for Annexin $\mathrm{V}$ staining and positive only for PI (Fig. 5), and because of the increase of apoptotic bodies in the transplanted tumors treated with the peptides as demonstrated by the TUNEL assay (Fig. 6C). These findings indicated that peptide delivery not only inhibited cell growth but also induced tumor cell apoptosis.

Since the in vitro experiment suggested the feasibility of treatment of renal cell carcinoma through peptide delivery, we experimentally treated tumors using a nude mouse model of transplanted human tumor. During the previously reported experiment in B cell lymphoma, peptides were directly inocu- lated as a single dose into the tissue surrounding a tumor formed by transplantation. Tumor shrinkage was then noted, but regrowth of the tumor was detected from day 5 after peptide inoculation (21). This finding suggested short-term stability of peptides after inoculation and thus a limited effect of treatment with single-dose peptide inoculation. In the present experimental treatment of renal cell carcinoma, we therefore compared a single-dose regimen with a regimen consisting of 3 doses administered at 1-week intervals. The single-dose regimen clearly provided a greater therapeutic effect than the control regimen, while the 3 -dose regimen provided much greater therapeutic effect; tumors had completely disappeared 28 days after the initiation of the first treatment (Fig. 6A and B). This finding indicates that renal cell carcinoma can be treated with the $16^{\mathrm{INK} 4 \mathrm{a}}$ peptide and that peptide therapy requires more than one dose.

The $\mathrm{p} 16^{\mathrm{INK} 4 \mathrm{a}}$ functional peptide and transporter peptide administered during the present study are not cell-specific. Since this complex is also delivered to normal cells, its toxicity becomes an issue. In a study conducted in patients with B cell lymphoma, peptide delivery was noted in normal lymphocytes, but induction of apoptosis was not (21). In addition, in experimental treatment of human glioma in mice with transplanted human glioma, the peptide was systemically administered via the heart, as was done in the present study (22). As a result, tumor shrinkage was noted, but no pathological abnormalities were detected in the normal cerebral tissue surrounding the transplanted tumor or in other normal organs. During the present experimental treatment in mice with transplanted human renal cell carcinoma, normal tissues (kidney, liver and spleen) were histologically examined. No significant differences or abnormalities were noted between the treated and untreated groups, and no abnormalities were seen. In the experiment performed to assess the effect on cell growth, cell growth was slightly inhibited by the use of $\mathrm{Wr}-\mathrm{T}$ alone, but the observational experiment did not reveal any apoptosis. These findings suggest that Wr-T delays the cell cycle, with no cell-killing effect.

The present findings indicate the efficacy of our therapy, in which a functional peptide is delivered using the transporter developed by our research group, for renal cell carcinoma. This therapy, which seems to have little effect on normal cells, will pave the way for clinical studies.

\section{Acknowledgements}

We are grateful to Mr. Makoto Naruse in Division of Advanced Research Promotion, Aichi Medical University for his technical assistance with FACSCanto data acquisition, and Ms. Shino Kojima and Ms. Norika Yamada in Department of Pathology, Aichi Medical University for their technical assistance.

\section{References}

1. Wirth MP: Immunotherapy for metastatic renal cell carcinoma. Urol Clin North Am 20: 283-295, 1993.

2. Fyfe G, Fisher RI, Rosenberg SA, Sznol M, Parkinson DR and Louie AC: Results of treatment of 255 patients with metastatic renal cell carcinoma who received high-dose recombinant interleukin-2 therapy. J Clin Oncol 13: 688-696, 1995.

3. Medical Research Council Renal Cancer Collaborators: Interferonalpha and survival in metastatic renal carcinoma: early results of a randomised controlled trial. Lancet 353: 14-17, 1999. 
4. Motzer RJ, Bacik J, Murphy BA, Russo P and Mazumdar M: Interferon-alfa as a comparative treatment for clinical trials of new therapies against advanced renal cell carcinoma. J Clin Oncol 20: 289-296, 2002.

5. Akaza H, Tsukamoto T, Onishi T, Miki T, Kinouchi $\mathrm{T}$ and Naito S: A low-dose combination therapy of interleukin-2 and interferon-alpha is effective for lung metastasis of renal cell carcinoma: a multicenter open study. Int J Clin Oncol 11: 434-440, 2006.

6. Klapper JA, Downey SG, Smith FO, Yang JC, Hughes MS, Kammula US, Sherry RM, Royal RE, Steinberg SM and Rosenberg S: High-dose interleukin-2 for the treatment of metastatic renal cell carcinoma: a retrospective analysis of response and survival in patients treated in the surgery branch at the National Cancer Institute between 1986 and 2006. Cancer 113: 293-301, 2008.

7. Gollob JA, Rathmell WK, Richmond TM, Marino CB, Miller EK, Grigson G, Watkins C, Gu L, Peterson BL and Wright JJ: Phase II trial of sorafenib plus interferon alfa- $2 \mathrm{~b}$ as first- or second-line therapy in patients with metastatic renal cell cancer. J Clin Oncol 25: 3288-3295, 2007.

8. Ryan CW, Goldman BH, Lara PN Jr, Mack PC, Beer TM, Tangen CM, Lemmon D, Pan CX, Drabkin HA and Crawford ED Southwest Oncology Group: Sorafenib with interferon alfa-2b as first-line treatment of advanced renal carcinoma: a phase II study of the Southwest Oncology Group. J Clin Oncol 25: 3296-3301, 2007.

9. Motzer RJ,Hutson TE, Tomczak P, Michaelson MD, Bukowski RM, Rixe O, Oudard S, Negrier S, Szczylik C, Kim ST, Chen I, Bycott PW, Baum CM and Figlin RA: Sunitinib versus interferon alfa in metastatic renal-cell carcinoma. N Engl J Med 356 : 115-124, 2007.

10. Motzer RJ, Escudier B, Oudard S, Hutson TE, Porta C, Bracarda S, Grünwald V, Thompson JA, Figlin RA, Hollaender N, Urbanowitz G, Berg WJ, Kay A, Lebwohl D and Ravaud A; RECORD-1 Study Group: Efficacy of everolimus in advanced renal cell carcinoma: a double-blind, randomised, placebocontrolled phase III trial. Lancet 372: 449-456, 2008.

11. Escudier B, Szczylik C, Hutson TE, Demkow T, Staehler M, Rolland F, Negrier S, Laferriere N, Scheuring UJ, Cella D, Shah S, Bukowski RM: Randomized phase II trial of first-line treatment with sorafenib versus interferon Alfa- $2 \mathrm{a}$ in patients with metastatic renal cell carcinoma. J Clin Oncol 27: 1280-1289, 2009.

12. Motzer RJ, Hudes GR, Curti BD, McDermott DF, Escudier BJ, Negrier S, Duclos B, Moore L, O'Toole T, Boni JP and Dutcher JP: Phase I/II trial of temsirolimus combined with interferon alfa for advanced renal cell carcinoma. J Clin Oncol 25: 3958-3964, 2007.

13. Green M and Loewenstein PM: Autonomous functional domains of chemically synthesized human immunodeficiency virus tat trans-activator protein. Cell 55: 1179-1188, 1988.

14. Frankel AD and Pabo CO: Cellular uptake of the tat protein from human immunodeficiency virus. Cell 55: 1189-1193, 1988.

15. Schwarze SR, Ho A, Vocero-Akbani A and Dowdy SF: In vivo protein transduction: delivery of a biologically active protein into the mouse. Science 285: 1569-1572, 1999.

16. Nagahara H, Vocero-Akbani AM, Snyder EL, Ho A, Latham DG, Lissy NA, Becker-Hapak M, Ezhevsky SA and Dowdy SF: Transduction of full-length TAT fusion proteins into mammalian cells: TAT-p27Kip1 induces cell migration. Nat Med 12: 1449-1452, 1998.
17. Derossi D, Joliot AH, Chassaing G and Prochiantz A: The third helix of the Antennapedia homeodomain translocates through biological membranes. J Biol Chem 269: 10444-104450, 1994.

18. Wender PA, Mitchell DJ, Pattabiraman K, Pelkey ET, Steinman L and Rothbard JB: The design, synthesis, and evaluation of molecules that enable or enhance cellular uptake: peptoid molecular transporters. Proc Natl Acad Sci USA 97: 13003-13008, 2000.

19. Fisher PM, Krausz E and Lane DP: Cellular delivery of impermeable effector molecules in the form of conjugates with peptides capable of mediating membrane translocation. Bioconjug Chem 12: 825-841, 2001

20. Joliot A and Prochiantz A: Transduction peptides: from technology to physiology. Nat Cell Biol 6: 189-196, 2004.

21. Kondo E, Seto M, Yoshikawa K and Yoshino T: Highly efficient delivery of p16 antitumor peptide into aggressive leukemia/ lymphoma cells using a novel transporter system. Mol Cancer Ther 3: 1623-1630, 2004.

22. Kondo E, Tanaka T, Miyake T, Ichikawa T, Hirai M, Adachi M, Yoshikawa K, Ichimura K, Ohara N, Moriwaki A, Date I, Ueda R and Yoshino T: Potent synergy of dual antitumor peptides for growth suppression of human glioblastoma cell lines. Mol Cancer Ther 7: 1461-1471, 2008.

23. Morris MC, Depollier J, Mery J, Heitz F and Divita G: A peptide carrier for the delivery of biologically active proteins into mammalian cells. Nat Biotechnol 19: 1173-1176, 2001.

24. Fahraeus R, Lain S, Ball KL and Lane DP: Characterization of the cyclin-dependent kinase inhibitory domain of the INK4 family as a model for a synthetic tumour suppressor molecule. Oncogene 16: $587-596,1998$

25. Arvanitis DA and Spandidos DA: Deregulation of the G1/S phase transition in cancer and squamous intraepithelial lesions of the uterine cervix: a case control study. Oncol Rep 20: 751-760, 2008.

26. Kwon TK, Buchholz MA, Chrest FJ and Nordin AA: Staurosporineinduced $\mathrm{G} 1$ arrest is associated with the induction and accumulation of cyclin-dependent kinase inhibitors. cell Growth Differ 7: 1305-1313, 1996.

27. Donnellan R and Chetty R: Cyclin D1 and human neoplasia. Mol Pathol 51: 1-7, 1998.

28. Sherr CJ and Roberts JM: CDK inhibitors: positive and negative regulators of G1-phase progression. Genes Dev 13: 1501-1512, 1999.

29. Ikuerowo SO, Kuczyk MA, von Wasielewski R, Shittu OB, Janas U, Machtens S, Serth J: p16INK4a expression and clinicopathologic parameters in renal cell carcinoma. Eur Urol 51: 732-737, 2007.

30. Scharml P, Struckmann K, Bendnar R, Fu W, Gasser T, Wilber K, Kononen J, Sauter G, Mihatsch MJ and Moch H: CDKNA2A mutation analysis, protein expression, and deletion mapping of chromosome $9 p$ in conventional clear-cell renal carcinomas: evidence for a second tumor suppressor gene proximal to CDKN2A. Am J Pathol 158: 593-601, 2001.

31. Kawada Y, Nakamura M, Ishida E, Shimada K, Oosterwijk E, Uemura H, Hirao Y, Chul KS and Konishi N: Aberrations of the p14(ARF) and p16(INK4a) genes in renal cell carcinomas. Jpn J Cancer Res 92: 1293-1299, 2001. 